\title{
Effects of herbicides diuron and atrazine on corals of the Great Barrier Reef, Australia
}

\author{
Ross J. Jones ${ }^{1, *}$, Jochen Muller ${ }^{2}$, David Haynes ${ }^{3}$, Ulrich Schreiber ${ }^{4}$ \\ ${ }^{1}$ Centre for Marine Studies, The University of Queensland, St Lucia Campus, Brisbane, Queensland 4072, Australia \\ ${ }^{2}$ National Research Centre for Environmental Toxicology (NRCET), Coopers Plains, Queensland 4121, Australia \\ ${ }^{3}$ Great Barrier Reef Marine Park Authority (GBRMPA), Townsville, Queensland 4810, Australia \\ ${ }^{4}$ Julius-von-Sachs Institut für Biowissenschaften, Universität Würzburg, Julius-von-Sachs-Platz 2, 97082 Würzburg, Germany
}

\begin{abstract}
In response to recent reports of contamination of the nearshore marine environment along the Queensland coast by herbicides (including areas inside the Great Barrier Reef Marine Park), an ecotoxicological assessment was conducted of the impact of the herbicides diuron and atrazine on scleractinian corals. Pulse-amplitude modulated (PAM) chlorophyll fluorescence techniques were used to assess the herbicide effects on the symbiotic dinoflagellates within the tissues (in hospite) of 4 species of coral (Acropora formosa, Montipora digitata, Porites cylindrica, Seriatopora hystrix) in static toxicity tests, and in freshly isolated symbiotic dinoflagellates from Stylophora pistillata. Using change in the effective quantum yield $\left(\Delta F / F_{m}{ }^{\prime}\right)$ as an effect criterion, diuron (no observable effect concentration, NOEC $=0.3 \mu \mathrm{g} \mathrm{l}^{-1}$; lowest observable effect concentration, LOEC $=1 \mu \mathrm{g} \mathrm{l^{-1 }}$; median effective concentration, $\mathrm{EC}_{50}=4$ to $6 \mathrm{\mu g} \mathrm{l}^{-1}$ ) was found to be more toxic than atrazine $\left(\mathrm{NOEC}=1 \mu \mathrm{g} \mathrm{l}^{-1}, \mathrm{LOEC}=3 \mu \mathrm{g} \mathrm{l}^{-1}, \mathrm{EC}_{50}=40\right.$ to $\left.90 \mu \mathrm{gl}^{-1}\right)$ in short-term $(10 \mathrm{~h})$ toxicity tests. In the tests with isolated algae, significant reductions in $\Delta F / F_{m}{ }^{\prime}$ were recorded as low as $0.25 \mu \mathrm{g} \mathrm{l}^{-1}$ diuron $\left(\mathrm{LOEC}, \mathrm{EC}_{50}=5 \mathrm{\mu g} \mathrm{l}^{-1}\right)$. Time-course experiments indicated that the effects of diuron were rapid and reversible. At $10 \mathrm{\mu g} \mathrm{l}^{-1}$ diuron, $\Delta F / F_{m}{ }^{\prime}$ was reduced by $25 \%$ in 20 to $30 \mathrm{~min}$, and by $50 \%$ in 60 to $90 \mathrm{~min}$. Recovery of $\Delta F / F_{m}{ }^{\prime}$ in corals exposed to $10 \mu \mathrm{g} \mathrm{l}^{-1}$ diuron and then transferred to running seawater was slower, returning to within $10 \%$ of control values inside 1 to $7 \mathrm{~h}$. The effect of a reduction in salinity ( 35 to $27 \%$ ) on diuron toxicity (at 1 and $3 \mu \mathrm{g} \mathrm{l}^{-1}$ diuron) was tested to examine the potential consequences of contaminated coastal flood plumes inundating inshore reefs. $\Delta F / F_{m}{ }^{\prime}$ was reduced in the diuron-exposed corals, but there was no significant interaction between diuron and reduced salinity seawater within the $10 \mathrm{~h}$ duration of the test. Exposure to higher (100 and $1000 \mu \mathrm{g}$ $\mathrm{l}^{-1}$ ) diuron concentrations for $96 \mathrm{~h}$ caused a reduction in $\Delta F / F_{m}{ }^{\prime}$, the ratio variable to maximal fluorescence $\left(F_{V} / F_{m}\right)$, significant loss of symbiotic dinoflagellates and pronounced tissue retraction, causing the corals to pale or bleach. The significance of the results in relation to diuron contamination of the coastal marine environment from terrestrial sources (mainly agricultural) and marine sources (antifouling paints) are discussed.
\end{abstract}

KEY WORDS: Coral Coral bleaching $\cdot$ Symbiotic dinoflagellate $\cdot$ Diuron $\cdot$ Atrazine $\cdot$ Herbicide $\cdot$ Chlorophyll fluorescence

Resale or republication not permitted without written consent of the publisher

\section{INTRODUCTION}

Recently, the herbicide diuron and the insecticides lindane, dieldrin and DDT have been detected in the nearshore marine environment along the Queensland coast, Australia (Haynes et al. 2000a). The substituted urea herbicide diuron was the most widely distributed, and was detected in intertidal and subtidal sediments and seagrasses at many locations along the 'wet-tropics' coastline. Many of the sediment and seagrass samples contaminated with diuron were located within the boundaries of the Great Barrier Reef Marine Park (GBRMP) and the Great Barrier Reef World Heritage Area (Haynes et al. 2000a). 
Of the 2900 reefs that comprise the Great Barrier Reef (GBR), a significant number ( 750) occur at coastal sites (Furnas \& Brodie 1996) and, compared with the outer and mid-shelf reefs, are subjected to pronounced and episodic changes in physical and chemical environmental conditions. Inshore reefs and the many isolated shoals and coral assemblages of the nearshore environment are also more susceptible to human activities of the coastal system. Concern has been expressed regarding the effects of herbicides such as diuron on corals and their symbiotic dinoflagellate microalgae (Haynes et al. 2000a,b). Nothing is known of the potential environmental effects of diuron on corals.

The Australian Inventory of Chemical Substances (AICS) run by the National Industrial Chemicals Notification and Assessment Scheme (NICNAS) lists diuron as used commercially in Australia as an antifouling agent (to prevent the growth of algae) and as a terrestrial herbicide (for weed control). All antifouling paints and herbicides intended for use in Australia require registration with the National Registration Authority for Agricultural and Veterinary chemicals (NRA) and approved substances are listed in the Australian NRA Registered Product Database (PUBCRIS). At the time of writing, there are 82 diuroncontaining products on the database, of which 60 are herbicides, 20 are antifouling paints and the remaining 2 products are associated with the control of algae in garden ponds and home aquaria. Therefore, diuron contamination of the east Australian coastal environment is likely to be either from marine sources (i.e. a planned release and related to antifouling) and/or terrestrial sources (i.e. inadvertent release from agriculture/industry and runoff). Many analyses of the water quality issues on the Great Barrier Reef in the last few years have not discussed antifouling paints as a potential source of diuron contamination in the Queensland marine environment.

\section{Marine sources}

Diuron is a commonly used biocide in paint preparations applied to offshore constructions, buoys, mariculture equipment and recreational and commercial vessels to prevent the build-up of marine algae. The use of diuron in antifouling stemmed from the phasing out of tri$n$-butyl tin (TBT) antifouling compounds on smaller vessels (<25 m length) in many countries in the late 1980s and early 1990s, amid concerns of widespread environmental degradation from tri-organotin (Alzieu 1996, Stewart 1996). This led to the promotion of copper-based antifouling paints and paints containing co-biocides (or 'booster' biocides) to increase the efficacy of the paints to more copper-resistant algal species (e.g. Enteromorpha spp.; Voulvoulis et al. 1999). In the antifouling process, herbicides and copper are released slowly into the marine environment through the hydrolysis and dissolution of a soluble vinyl or synthetic polymer binder resin. More rapid release of biocides may also occur over shorter time periods during painting and paint-stripping processes (i.e. high-pressure hosing), and through ship groundings (Haynes et al. 2002). Further plans by the International Maritime Organization (IMO) are imminent to phase out TBT-based antifouling paints on commercial vessels by the year 2003 and completely ban their use by 2008 (Evans et al. 2000); this will most likely increase the use of copper-based antifouling paints and antifouling paints with co-biocides.

Contamination of the marine environment by diuron has been reported in many recent studies. In the United Kingdom and Spain, diuron has been detected in several estuaries which have high levels of recreational boating (Boxall et al. 2000, Thomas et al. 2000, Martinez et al. 2001). Concentrations of diuron in marinas were an order of magnitude higher in summer compared to winter (Boxall et al. 2000), and these areas are not adjacent to catchments where diuron is used as an agricultural herbicide. Diuron has also been detected in marine coastal waters at higher concentrations than in freshwaters. Collectively, these observations have been used to infer a 'marine' (i.e. antifouling paint) source of the diuron contamination in the coastal environment.

The recent identification of Irgarol 1051 in the Queensland marine environment (Scarlett et al. 1999) is particularly relevant to coastal marine contamination from antifouling paint sources. Irgarol 1051 (2-methylthio-4-tertiary-butylamino-6-cyclopropylamino-s-terazine) is an $s$-triazine herbicide commonly used as a booster biocide in antifouling paint products (Voulvoulis et al. 1999). Contamination of the marine environment by Irgarol 1051 and its breakdown products has been widely reported in the temperate marine environment (see Voulvoulis et al. 2000). Despite never having been approved for use in Australia, Irgarol 1051 has also been detected in seagrasses along the eastern seaboard of Australia, including 2 areas inside the GBRMP (Scarlett et al. 1999). The contamination is thought to have occurred either from passing ships or visiting yachts, or from the illegal sales of an antifouling paint positively identified as containing Irgarol 1051. Since Irgarol 1051 is not used in the agricultural sector, its presence in the marine environment can solely be attributed to contamination by antifouling paint.

\section{Terrestrial sources}

Phenylurea herbicides are used extensively in agriculture and horticulture. Diuron, in particular, is used 
in pre-emergence control programs to control germinating grasses and dicotyledonous weeds. In general, it is not used outside the agricultural/horticultural sector (i.e. for weed control on roads, railways, parks, sporting fields etc). However, 15 tonnes (t) per annum of Kromac Industrial Herbicide (Macspred Pty, containing $40 \%$ diuron and $40 \%$ bromacil) is used for controlling weeds on railway tracks in Queensland (Queensland Rail, Environmental Services, pers. comm.).

Catchments of 15 rivers, comprising an area of $375000 \mathrm{~km}^{2}$, drain into the GBRMP (Johnson \& Ebert 2000). Grazing (beef production) is the single largest use of the catchment area, followed by cropping (mostly sugarcane but also cotton farming) and urban/ residential development (Brodie et al. 2001). Sugarcane growing areas cover approximately $2 \%$ of the entire Queensland catchment area and range from the far north to south, mostly within $50 \mathrm{~km}$ of the coastline (Hamilton \& Haydon 1996). Both sugarcane and cotton farming rely on intensive plant protection using pesticides (herbicides, insecticides, fungicides), and in Queensland cane farming $90 \%$ of the pesticides used are herbicidal, $8 \%$ are insecticidal and $2 \%$ are fungicidal (Hamilton \& Haydon 1996). In a detailed study of one of the 15 river catchment areas (the Herbert catchment) Johnson \& Ebert (2000) indicated that $7 \%$ of the total catchment area $\left(10000 \mathrm{~km}^{2}\right)$ received pesticides, of which $95 \%$ of total applications occurred in sugarcane growing areas. In the same catchment, the area used for sugarcane production has nearly tripled in the last $50 \mathrm{yr}$, and pesticide usage has increased accordingly (Johnson \& Ebert 2000).

Diuron is the second most commonly used herbicide in the 5 major regions that make up the Queensland catchment area (North, Herbert, Burdekin, Central, South); atrazine is the most frequently used (Hamilton \& Haydon 1996). Approximately $50 \%$ of the diuron use occurs in the Central section, with differences in diuron usage between regions reflecting different weed problems and farming techniques (Hamilton \& Haydon 1996). The potential off-site movement of pesticides and pesticide residues depends upon numerous factors including (1) the size and source of the pesticide, (2) biophysical properties of the ion or molecule, (3) the nature of the soil, (4) the hydrology of the landscape, and (5) local environmental conditions. Sorption-desorption, volatilization, chemical and biological degradation, plant uptake, surface runoff and leaching (biotic and abiotic) are the most important processes influencing transport (for reviews see Kookana et al. 1998).

Overall, diuron represents the pesticide of greatest environmental concern (Haynes et al. 2000b, Williams 2001) on account of the volume used, its persistence in the soil and leachability. For example, an estimated $197 \mathrm{t}$ of diuron (and $331 \mathrm{t}$ of atrazine) are used in the sugarcane industry per year (Hamilton \& Haydon 1996). The field half-life of diuron can vary from 13 to $>250 \mathrm{~d}$, and despite being only moderately soluble in water $\left(0.042 \mathrm{mg} \mathrm{l}^{-1}\right)$, it is not tightly bound to soil particles (Simpson et al. 1999). The potential for off-site contamination by diuron is well known. Several studies have detected herbicides and herbicide residues in cane farm irrigation areas (Müller et al. 2000), groundwaters in the Lower Pioneer River catchment area (Baskaran et al. 2002), and rivers of the Fitzroy Catchment area (Noble et al. 1997), Johnston Basin (Hunter et al. 2001) and Pioneer River (White et al. 2002). Diuron and other herbicides have been detected in sediments in mangrove plots in the Pioneer River estuary and in the Mackay region (Duke et al. 2001). In a comprehensive assessment of pesticide and herbicide contamination of the Great Barrier Reef World Heritage area and Queensland coast, Haynes et al. (2000a) reported detectable diuron concentrations in intertidal sediments and sea grasses between Cairns and Cardwell, and in intertidal sea grass samples collected near Townsville. Diuron was also present in 8 of 25 subtidal sediment samples collected between Horn Island (Torres Strait) and Gladstone. All of the samples that tested positive for diuron were located between Lucinda and Port Douglas, where sugarcane is grown. Diuron was not detected north of Port Douglas, where sugarcane is absent.

In this study, the potential environmental effects of diuron on the symbiotic dinoflagellates of corals in the host tissue (in hospite) and isolated from the host (in vivo) are examined. Particular attention is given to the time-course of effect and recovery of symbiont photosynthetic efficiency following diuron exposure, because of the unusual location of the algal symbionts in corals (i.e. isolated from the surrounding seawater by vacuolization within a specialized compartment of the 'host' coral cells). Diuron phytotoxicity is also compared to that of atrazine, the most commonly used herbicide in the GBR catchment area. The response of corals to diuron in reduced-salinity seawater is also measured, to simulate the potential effects of inundation of a coastal reef by contaminated flood plumes.

\section{MATERIALS AND METHODS}

All experiments were undertaken at the Heron Island Research Station (HIRS, $23^{\circ} 26^{\prime} \mathrm{S}, 151^{\circ} 55^{\prime} \mathrm{E}$ ), located $65 \mathrm{~km}$ east of mainland Australia in the Capricorn-Bunker group of reefs in the southern Great Barrier Reef. Using surgical bone cutters, vertically oriented coral branches (4 to $6 \mathrm{~cm}$ long) were cut from the centre of colonies of 3 species of coral, e.g. Acropora formosa (Dana, 1846; family Acroporidae), Mon- 
tipora digitata (Dana, 1846; family Acroporidae), and Porites cylindrica (Dana, 1846; family Poritidae), living on the inner and outer sub-tidal protected reef flat ( 0.25 to $2 \mathrm{~m}$ depth) of Heron Island reef. The bases of the cut branches were sealed with a 2-part epoxy polymer (Selleys, New South Wales) and then mounted, using modelling clay, onto small numbered plastic holders. Experiments were also conducted with small (1 to $2 \mathrm{~cm}$ long) branches of Seriatopora hystrix (Dana 1846, family Pocilloporidae) from colonies located on the top of the protected sub-tidal reef slope. Branches were mounted onto plastic holders. All coral fragments were held for at least 1 to $2 \mathrm{~d}$ in running seawater at $50 \%$ ambient light level (or $25 \%$ for $S$. hystrix) manipulated using shade-cloth above the test corals for $2 \mathrm{~d}$ before any experiments.

Toxicity tests. Short-term, static toxicity tests were conducted to evaluate the relative toxicity of the herbicides diuron ( $\mathrm{N}^{\prime}$-[3,4-dichlorophenyl]-N,N-dimethylurea) and atrazine (6-chloro-N-ethyl-N-[1-methylethyl]-1,3,5-triazine-2,4-diamine, Sigma Pharmaceuticals) on the symbiotic dinoflagellates of the corals Acropora formosa, Montipora digitata, Porites cylindrica and Seriatopora hystrix. Tests were conducted in glass beakers using 21 of test solution and incubated at $25 \pm 1^{\circ} \mathrm{C}$ under artificial lights (Colour 11 fluorescent light, Osram, Germany) at $120 \mu \mathrm{mol}$ quanta $\mathrm{m}^{-2}$ $\mathrm{s}^{-1}$ photosynthetically active radiation (PAR, 400 to $700 \mathrm{~nm}$, measured using a LI-190SA quantum sensor; LI-COR) under a 10:14 h light:dark cycle. Incubation chambers were stirred for $0.5 \mathrm{~h}$ every $2 \mathrm{~h}$ using magnetically coupled stir bars. For $S$. hystrix, all experiments were conducted in glass beakers using $200 \mathrm{ml}$ of test solution under 100 or $25 \mu \mathrm{mol}$ quanta $\mathrm{m}^{-2} \mathrm{~s}^{-1}$ PAR provided by (Colour 11 fluorescent light, Osram). Incubation chambers were stirred continuously using magnetically coupled stir bars. Experiments were conducted in fresh seawater of the HIRS aquarium system that is pumped from a submarine intake at 5 to $6 \mathrm{~m}$ depth on the reef slope to a 200001 header tank for settlement before discharge through the aquarium system. All seawater used in the toxicity tests was filtered to $1 \mu \mathrm{m}$ (nominal levels) using a $1 \mu \mathrm{m}$-spun polypropylene filter cartridge (PPI Corporation).

In each toxicity test, 5 concentrations of diuron $(0.3$, $\left.1,3,10,30 \mathrm{\mu g}^{-1}\right)$ or atrazine $\left(1,3,10,30,100 \mu \mathrm{g} \mathrm{l}^{-1}\right)$ and 1 control (filtered seawater + carrier, $200 \mu \mathrm{l}$ max.) were used, and 3 randomly located replicate containers were used at each concentration or control. At the start of the test, 3 coral fragments (or $n=6$ fragments of Seriatopora hystrix) were transferred to each of the test containers and the lights were turned on. After $10 \mathrm{~h}$, chlorophyll fluorescence parameters were measured to determine $\Delta F / F_{m}{ }^{\prime}$ (see later subsection) and the corals were then incubated in darkness for a further $14 \mathrm{~h}$ before measuring the chlorophyll fluorescence parameters to determine $F_{v} / F_{m}(t=24 \mathrm{~h})$. Corals were then returned to running seawater in the holding tank under natural sunlight which was reduced to $50 \%$ of ambient by neutral density shade-cloth. $\Delta F / F_{m}{ }^{\prime}$ was measured again at $34 \mathrm{~h}$. For studies with $S$. hystrix, the effects of the incubation irradiance was tested in separate toxicity tests conducted under either 100 or $25 \mu \mathrm{mol}$ quanta $\mathrm{m}^{-2} \mathrm{~s}^{-1}$ PAR.

Exposure and recovery experiments. To examine the time-course of the effect of diuron on corals, coral fragments were exposed to diuron concentrations under $120 \mu \mathrm{mol}$ quanta $\mathrm{m}^{-2} \mathrm{~s}^{-1}$ PAR (artificial light) for $4 \mathrm{~h}$ and chlorophyll fluorescence parameters were measured to determine $\Delta F / F_{m}{ }^{\prime}$ at regular intervals for 200 min. During each experiment, corals were incubated in $2 \mathrm{l}$ of $10 \mathrm{\mu g} \mathrm{l}^{-1}$ diuron and $\Delta F / F_{m}{ }^{\prime}$ was expressed as a percentage of control corals incubated in $2 \mathrm{l}$ of filtered ambient seawater (+ carrier). Uptake experiments were repeated 3 times for each species with 4 corals per test or control container. All experiments were started in the early morning period, using corals that had been removed from the flowing seawater aquarium and held under reduced $(<5 \mu$ mol quanta $\mathrm{m}^{-2} \mathrm{~s}^{-1}$ ) PAR levels for $1 \mathrm{~h}$ before experimentation.

To examine the recovery rates of corals from diuron, coral fragments were exposed to elevated diuron under $120 \mu$ mol quanta $\mathrm{m}^{-2} \mathrm{~s}^{-1}$ PAR (artificial light) for $4 \mathrm{~h}$ and then $\Delta F / F_{m}{ }^{\prime}$ was measured. Corals were subsequently transferred to a $25 \mathrm{l}$ aquarium receiving a running supply $\left(2.51 \mathrm{~min}^{-1}\right)$ of fresh seawater and incubated under $120 \mu \mathrm{mol}$ quanta $\mathrm{m}^{-2} \mathrm{~s}^{-1}$ PAR (artificial light) for $500 \mathrm{~min} . \Delta F / F_{m}{ }^{\prime}$ was measured at regular intervals for up to $8 \mathrm{~h}$ and expressed as a percentage of control corals exposed to ambient seawater only during the $4 \mathrm{~h}$ incubations. The recovery rate experiments were repeated 3 times for each species with 3 corals per test or control container. All experiments were started in the early morning period, using corals that had been removed from the flowing seawater aquarium and held under reduced $(<5 \mu \mathrm{mol}$ quanta $\mathrm{m}^{-2} \mathrm{~s}^{-1}$ ) PAR levels for $1 \mathrm{~h}$ before experimentation.

Salinity and diuron interaction. To examine the effects of a reduction in the salinity of seawater during exposure to diuron, corals were exposed to low concentrations of diuron $\left(1\right.$ or $\left.3 \mu \mathrm{g} \mathrm{l}^{-1}\right)$ in either normal salinity $(35 \%)$ or reduced salinity $(27 \%)$ seawater in short-term $(10 \mathrm{~h})$ static toxicity tests, using the procedures and protocols described in the earlier subsection for the toxicity tests. Salinity levels were reduced by diluting filtered (1 $\mu \mathrm{m}$ nominal level) ambient seawater with distilled water.

Chronic tests. Longer-term semi-static (renewal) toxicity tests were conducted to examine the effects of 
diuron exposure on Montipora digitata. Corals were exposed to $0.1,1,10,100$ and $1000 \mu g l^{-1}$ diuron for $96 \mathrm{~h}$, and chlorophyll fluorescence parameters were measured at regular intervals during the exposure period and for a further $96 \mathrm{~h}$ observation period after transfer of the fragments to flowing seawater. At each dilution and in the controls, 3 corals were incubated in each of three 21 beakers and the beakers were semi-submerged in a 5001 fibreglass container receiving a running supply of seawater (for temperature regulation). All experiments were conducted under natural sunlight, which was reduced to $50 \%$ of ambient by positioning neutral density shade-cloth above the test containers. During experiments, PAR was recorded using a Dataflow Systems (New South Wales) terrestrial cosine photosynthetic irradiance sensor calibrated against a LI-COR Li190SA sensor. Average irradiance levels (over 10 min intervals) were recorded onto a Dataflow 392 data recorder. Water temperature $\left({ }^{\circ} \mathrm{C}\right)$ was measured using Optic Stowaway $^{\circledR}$ temperature loggers (accuracy $\pm 0.1^{\circ} \mathrm{C}$ ) calibrated against a NATA-certified (National Association of Testing Authorities) thermometer. Test controls (TC) were exposed to ambient seawater only (+ acetone carrier) during the experiments. To examine the effects of experimentally enclosing the corals, a set of 9 mounted coral fragments (handling controls, HC) were placed in the running seawater container beside the test chambers.

Test and control solutions were changed daily, and during this procedure the corals were briefly transferred to flowing seawater and then transferred back to the freshly made test solutions. This procedure took less than $20 \mathrm{~min}$. The experiment was started $2 \mathrm{~h}$ after sunset and chlorophyll fluorescence parameters were measured on subsequent days at solar noon $\left(\Delta F / F_{m}{ }^{\prime}\right)$ and $2 \mathrm{~h}$ after sunset $\left(F_{V} / F_{m}\right)$. At the end of the experiment the corals were frozen for biomass analysis.

Tests with isolated symbiotic dinoflagellates. All experimental work was conducted with symbiotic dinoflagellates isolated from the coral Stylophora pistillata (Esper, 1797; family Pocilloporidae) collected from the protected intertidal reef flat at Heron Island. Symbiotic dinoflagellates were collected in filtered $(0.45 \mu \mathrm{m})$ seawater (FSW) by abrading the surface of the coral with a nylon brush. Algae were centrifuged at $1500 \times g$ for $3 \mathrm{~min}$ and the supernatant discarded. The algal pellet was re-suspended in $10 \mathrm{ml}$ of $0.45 \mu \mathrm{m}$ filtered seawater and the process repeated 3 times. Finally the algal pellet was re-suspended in $10 \mathrm{ml}$ of FSW. The algal density was counted with a haemacytometer (Improved Neubauer) under a light microscope ( $\mathrm{n}=8$ replicate counts) and adjusted by the addition of FSW to the desired algal density. The effects of diuron were measured at 6 concentrations in the range
0.25 to $25 \mu \mathrm{g} \mathrm{l}^{-1}$ using a dual-channel PAM fluorometer (ToxY-PAM dual channel yield analyzer, see following subsection).

Processing of corals. Coral tissues were stripped from the skeletons with a jet of re-circulated filtered seawater. The slurry produced from the tissuestripping process was homogenised in a blender for $30 \mathrm{~s}$ and the volume of the homogenate was recorded. Sub-samples $(10 \mathrm{ml})$ of the homogenate were taken to determine the number of symbiotic dinoflagellates and chlorophyll concentration. The number of symbiotic dinoflagellates was estimated using a haemacytometer (8 replicate counts), and total symbiotic dinoflagellates per coral were calculated after correcting for the sub-sampling. Chlorophyll a was determined in 2 subsamples of the tissue homogenate which were cen-

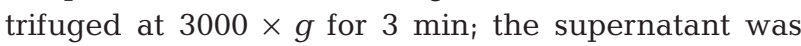
discarded, leaving an algal pellet. The pellet was resuspended in $100 \%$ acetone and left for $24 \mathrm{~h}$ at $4^{\circ} \mathrm{C}$. The extracts were then re-centrifuged at $3000 \times g$ for $3 \mathrm{~min}$ and the absorbances of the supernatant solutions were read on a spectrophotometer. The surface area of the coral skeleton was measured using the paraffinwax technique (Stimson \& Kinzie 1991). The number of symbiotic dinoflagellates was expressed per unit surface area $\left(\mathrm{cm}^{2}\right)$, and chlorophyll concentration as per unit surface area or per symbiotic dinoflagellate (determined by dividing by the number of symbiotic dinoflagellates in the sample: see Jones et al. 2000 for techniques on tissue extraction, chlorophyll analysis and surface area determination).

Chlorophyll fluorescence measurements. Chlorophyll fluorescence parameters of symbiotic dinoflagellates still in the host tissue of the coral (in hospite) were measured using a DIVING-PAM chlorophyll fluorometer (Walz GmbH). Measurements were always made on a vertical plane of tissue 2 to $3 \mathrm{~cm}$ above the base of the corals by placing the fibre-optic of the DIVING-PAM gently against the surface of the coral. Accurate placement of the fibre-optic was often facilitated by use of a micromanipulator. After a 5 to $10 \mathrm{~s}$ settling period, the initial fluorescence $\left(F_{0}\right)$ was determined by applying weak pulse-modulated red measuring light $\left(0.15 \mu \mathrm{mol}\right.$ quanta $\left.\mathrm{m}^{-2} \mathrm{~s}^{-1}\right)$. A saturating pulse (800 ms) of actinic light (>3000 $\mu$ mol quanta $\mathrm{m}^{-2}$ $\mathrm{s}^{-1}, 650 \mathrm{~nm}$ ) was then applied to measure maximum fluorescence $\left(F_{m}\right)$. The change in fluorescence from $F_{0}$ to $F_{m}$ denotes the variable fluorescence, $F_{\mathrm{V}}$ and the ratio of variable to maximal fluorescence in a darkadapted sample is correlated to the maximum quantum yield of photosynthesis (Butler 1978) observed when all PS II reaction centres are open and nonphotochemical loss of excitation energy (heat dissipation) is minimal (for reviews see Krause \& Weis 1991, Schreiber et al. 1994). 
$\frac{F_{m}-F_{0}}{F_{m}}=\frac{F_{V}}{F_{m}}=$ maximum potential quantum yield

In illuminated samples, there is partial closure of reaction centres and heat dissipation is stimulated (non-photochemical quenching), leading to an increase of fluorescence yield, $F$, with respect to $F_{0}$ and a decrease of maximal fluorescence yield, $F_{m}{ }^{\prime}$, with respect to $F_{m}$. The new value $\Delta F / F_{m}{ }^{\prime}$ is a measure of the effective quantum yield of PS II in an illuminated sample.

$\frac{F_{m}{ }^{\prime}-F}{F_{m}{ }^{\prime}}=\frac{\Delta F}{F_{m}{ }^{\prime}}=$ maximum effective quantum yield

Experiments on freshly isolated algae (in vitro) were made using a prototype version of a ToxY-PAM dual channel yield analyzer chlorophyll fluorometer (Walz $\mathrm{GmbH}$ ). One $\mathrm{ml}$ aliquots of the algae suspension were added to 2 quartz cuvettes (15 mm diameter) inserted into the 2 emitter-detector chambers (Channel 1 and Channel 2) of the fluorometer. After a 5 to $10 \mathrm{~s}$ settling period, the effective quantum yields of the 2 samples, $\Delta F / F_{m}{ }^{\prime}$ (Eq. 2) were measured repetitively every $30 \mathrm{~s}$ by an automated sequence of saturation pulses applied to the 2 samples. The system calculated the relative inhibition of Sample 1 (containing the herbicide) with respect to Sample 2 (control). The mean $( \pm \mathrm{SD}) \%$ inhibition was calculated for the period between 2.5 and $8 \mathrm{~min}$. Details of the operational procedures and proto-

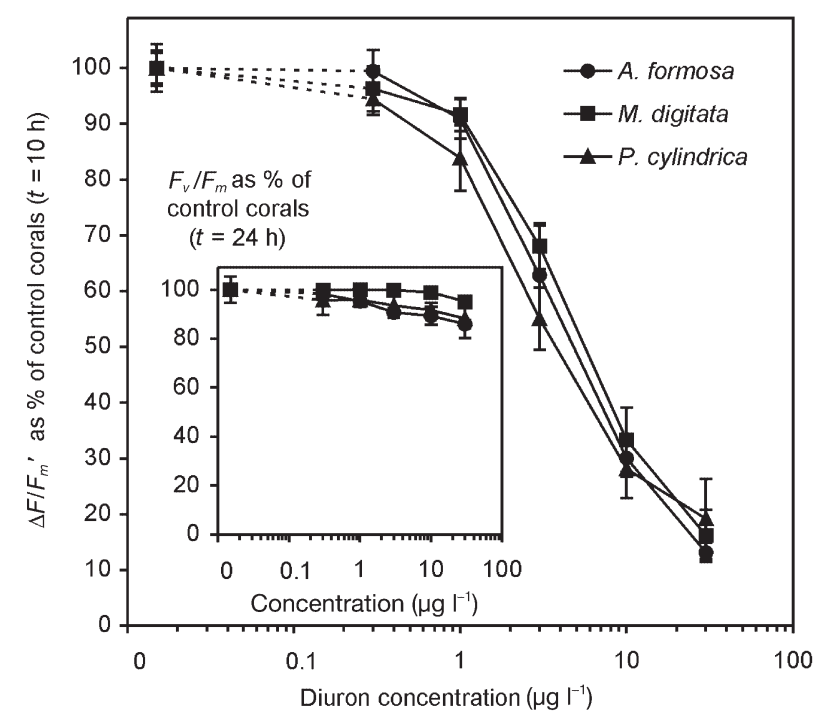

Fig. 1. Acropora formosa, Montipora digitata, and Porites cylindrica. Effective quantum yield $\left(\Delta F / F_{m}{ }^{\prime}\right)$ of symbiotic dinoflagellates measured in hospite in 3 species of coral exposed to elevated diuron concentrations in the range 0.3 to 30 $\mu \mathrm{g} \mathrm{l} \mathrm{l}^{-1}$ for $10 \mathrm{~h}$. All measurements were made at the end of the $10 \mathrm{~h}$ light period. Inset: $F_{\mathrm{V}} / F_{m}$ after $24 \mathrm{~h}$, measured at the end of the $14 \mathrm{~h}$ dark period. Data are mean $(\bar{x}) \pm \mathrm{SD}, \mathrm{n}=9$ cols associated with this device have recently been described in Schreiber et al. (2002). This instrument deliberately applies a relatively strong measuring light (3 $\mu$ mol quanta $\mathrm{m}^{-2} \mathrm{~s}^{-1}$ ) in order to induce a substantial rate of intersystem electron transport which is higher than intrinsic charge recombination at the PS II reaction centres.

Data analysis. Hypothesis testing and point-estimate procedures were used to assess and compare diuron and atrazine toxicity to the 3 different coral species using 3 statistical parameters, no observed effect concentration (NOEC), the lowest observed effect concentration (LOEC) and the effective concentration $\left(\mathrm{EC}_{\mathrm{x}}\right)$. The NOEC is the highest concentration not producing a significant response, whilst the LOEC is the lowest tested concentration causing an effect. Data were first arcsine-transformed and then tested for normality of distribution (Kolmogrov D-test) and homogeneity of variance (Bartlett's test). Data passing these criteria were tested using analysis of variance (ANOVA) and Dunnett's test to examine significant differences between herbicide-treated and control (solvent only; see Rand \& Petrocelli 1985) corals. Data that did not pass the criteria were analysed using Steel's many-one rank test. The concentrations causing a 50 and $25 \%$ reduction in the effect parameter (i.e. $\mathrm{EC}_{50}$ and $\mathrm{EC}_{25}$ ) were calculated by maximum likelihood regression using the probit transformation (probit analysis). All calculations were made using United States Environmental Protection Agency-approved software (ToxCalc ${ }^{\mathrm{TM}}$ Version 5.0, Tidepool Scientific Software).

\section{RESULTS}

After a $10 \mathrm{~h}$ exposure, significant differences in the $\Delta F / F_{m}$ ' of the symbiotic dinoflagellates in hospite were recorded between control corals and Acropora formosa, Montipora digitata and Porites cylindrica exposed to diuron concentrations $\geq 1 \mu \mathrm{g}^{-1}$ (NOEC $=0.3 \mu \mathrm{g} \mathrm{l^{-1 }}$, LOEC $=1 \mu \mathrm{g} \mathrm{l}^{-1}$ diuron). The $\mathrm{EC}_{50}$ and $\mathrm{EC}_{25}$ values $( \pm \mathrm{SD})$ were also similar for each species: $A$. formosa, $\mathrm{EC}_{50}=5.1 \pm$ $0.4 \mu \mathrm{g} \mathrm{l}^{-1}$ and $\mathrm{EC}_{25}=2 \pm 0.1 \mu \mathrm{g} \mathrm{l}^{-1}$ diuron; $M$. digitata, $\mathrm{EC}_{50}=5.9 \pm 0.2 \mu \mathrm{g} \mathrm{l}^{-1}$ and $\mathrm{EC}_{25}=2.2 \pm 0.1 \mu \mathrm{g} \mathrm{l}^{-1} ;$ P. cylindrica, $\mathrm{EC}_{50}=4.3 \pm 0.4 \mu \mathrm{g} \mathrm{l}^{-1}$ and $\mathrm{EC}_{25}=1.6 \pm 0.1 \mu \mathrm{g} \mathrm{l}^{-1}$ (Fig. 1). After $24 \mathrm{~h}$ exposure to elevated diuron concentrations, $F_{V} / F_{m}$ (measured at the end of the $14 \mathrm{~h}$ dark cycle) was significantly different from control corals in A. formosa exposed to $\geq 1 \mu \mathrm{g} \mathrm{l}^{-1}$, in $M$. digitata exposed to $30 \mu \mathrm{g} \mathrm{l}^{-1}$ and in P. cylindrica exposed to $\geq 3 \mu \mathrm{g} \mathrm{l^{-1 }}$ diuron. Corals were transferred to clean running seawater and, after a further $10 \mathrm{~h}$ in ambient light, no significant differences were detected between control corals and the highest concentration tested ( $30 \mu \mathrm{g} \mathrm{l}^{-1}$, ANOVA $\mathrm{p}>0.05$, data not shown). 


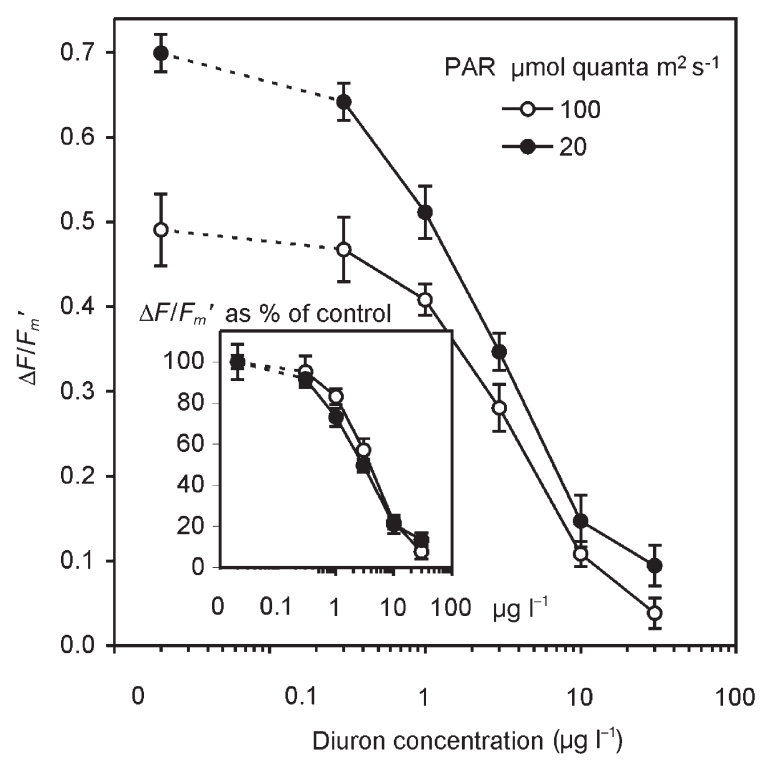

Fig. 2. Seriatopora hystrix. $\Delta F / F_{m}$ ' of symbiotic dinoflagellates measured in hospite in $S$. hystrix exposed to elevated diuron concentrations in the range 0.3 to $30 \mathrm{\mu g} \mathrm{l}^{-1}$ for $10 \mathrm{~h}$ under 20 or $100 \mu \mathrm{mol}$ quanta $\mathrm{m}^{-2} \mathrm{~s}^{-1}$. All measurements were made at the end of the $10 \mathrm{~h}$ light period. Inset: $\Delta F / F_{m}{ }^{\prime}$ expressed as \% of control values. Data are mean $(\bar{x}) \pm \mathrm{SD}, \mathrm{n}=12$

In Seriatopora hystrix, collected from a shaded environment, the effects of elevated diuron concentrations at different incubation light intensities were examined. At $100 \mu \mathrm{mol}$ quanta $\mathrm{m}^{-2} \mathrm{~s}^{-1} \mathrm{PAR}$, the NOEC, LOEC and $\mathrm{EC}_{50}$ and $\mathrm{EC}_{25}$ values were similar to those of the other species tested $\left(\right.$ NOEC $=0.3 \mu \mathrm{g} \mathrm{l}^{-1}$, LOEC $=1 \mu \mathrm{g} \mathrm{l^{-1 }}$, $\mathrm{EC}_{50}=3.7 \pm 0.2 \mu \mathrm{gl}^{-1}, \mathrm{EC}_{25}=1.5 \pm 0.1 \mu \mathrm{g} \mathrm{l}^{-1}$ diuron; Fig. 2). At $20 \mu \mathrm{mol}$ quanta $\mathrm{m}^{-2} \mathrm{~s}^{-1} \mathrm{PAR}$, a significant effect was detected at the lowest (NOEC $<0.3 \mu \mathrm{g} \mathrm{l}^{-1}$, LOEC $=0.3 \mu \mathrm{g} \mathrm{l}^{-1}$, diuron), concentration tested and $\mathrm{EC}_{50}$ and $\mathrm{EC}_{25}$ values were lower than at $100 \mu \mathrm{mol}$ quanta $\mathrm{m}^{-2} \mathrm{~s}^{-1}\left(\mathrm{EC}_{50}=2.9 \pm 0.2 \mu \mathrm{gl}^{-1}, \mathrm{EC}_{25}=1 \pm 0.1 \mu \mathrm{g}\right.$ $\mathrm{l}^{-1}$ diuron; Fig. 2).

After a $10 \mathrm{~h}$ exposure to atrazine, significant differences in $\Delta F / F_{m}{ }^{\prime}$ of the symbiotic dinoflagellates in hospite were recorded between control corals and corals exposed to concentrations $\geq 3 \mu \mathrm{g} \mathrm{l}^{-1}$ for Acropora formosa, Montipora digitata and Porites cylindrica. Thus the NOEC and LOEC values were 1 and $3 \mu \mathrm{g} \mathrm{l}^{-1}$ atrazine respectively for each species. The $\mathrm{EC}_{50}$ and $\mathrm{EC}_{25}$ values ( $\pm \mathrm{SD}$ ) were: $A$. formosa, $\mathrm{EC}_{50}=37 \pm 0.2 \mu \mathrm{g}$ $\mathrm{l}^{-1}$ and $\mathrm{EC}_{25}=14.5 \pm 0.3 \mu \mathrm{g} \mathrm{l}^{-1}$ atrazine; $M$. digitata, $\mathrm{EC}_{50}=88.2 \mu \mathrm{g} \mathrm{l}^{-1}$ and $\mathrm{EC}_{25}=25.5 \pm 0.6 \mu \mathrm{g} \mathrm{l}^{-1} ;$ P. cylindrica, $\mathrm{EC}_{50}=67.2 \pm 0.9 \mu \mathrm{g} \mathrm{l}^{-1}$ and $\mathrm{EC}_{25}=22.1 \pm 0.5 \mu \mathrm{g}$ $\mathrm{l}^{-1}$ (Fig. 3). These were approximately 1 order of magnitude higher than the $\mathrm{EC}_{50}$ and $\mathrm{EC}_{25}$ values recorded for diuron (Figs. 1 \& 2). After $24 \mathrm{~h}$ exposure to elevated atrazine concentrations, $F_{v} / F_{m}$ (measured at the end of the $14 \mathrm{~h}$ dark cycle) was not significantly different from control corals in any of the species at the highest concentration tested (100 $\mathrm{\mu g} \mathrm{l}^{-1}$ atrazine; Fig. 3). Corals were transferred to clean running seawater, and after a further $10 \mathrm{~h}$ in ambient light no significant differences were detected between control corals and the highest concentration tested (100 $\mu \mathrm{g} \mathrm{l}^{-1}$, data not shown).

Fig. 4 shows the time-dependence of the diuroninduced suppression of effective PS II quantum yield. Ten $\mu \mathrm{g} \mathrm{l}^{-1}$ diuron caused a significant decrease in $\Delta F / F_{m}^{\prime}$ in the symbiotic dinoflagellates in hospite for each of the 3 species tested within $10 \mathrm{~min} . \Delta F / F_{m}{ }^{\prime}$ decreased by $25 \%$ in $21 \mathrm{~min}$ for Acropora formosa, $25 \mathrm{~min}$ for Montipora digitata and $27 \mathrm{~min}$ for Porites cylindrica. $\Delta F / F_{m}{ }^{\prime}$ decreased by $50 \%$ in 58 min for A. formosa, 87 min for M. digitata, and 71 min for P. cylindrica.

The recovery kinetics after washing with uncontaminated seawater is shown in Fig. 5. After 250 min exposure to $10 \mu \mathrm{g} \mathrm{l}^{-1}$ diuron, $\Delta F / F_{m}{ }^{\prime}$ of the symbiotic dinoflagellates in hospite of the 3 species tested recovered rapidly following transfer to running seawater, recovering to within $25 \%$ of control values in $\sim 40$ min for Acropora formosa and $\sim 60 \mathrm{~min}$ Montipora digitata, (Fig. 5). Recovery of $\Delta F / F_{m}{ }^{\prime}$ for Porites cylindrica took slightly longer, returning to $25 \%$ of control values in $\sim 120$ min.

Acropora formosa and Montipora digitata fragments were exposed to low (1 and $3 \mu \mathrm{g} \mathrm{l}^{-1}$ ) diuron concentrations in either normal $(35 \%)$ or reduced-salinity $(27 \%)$

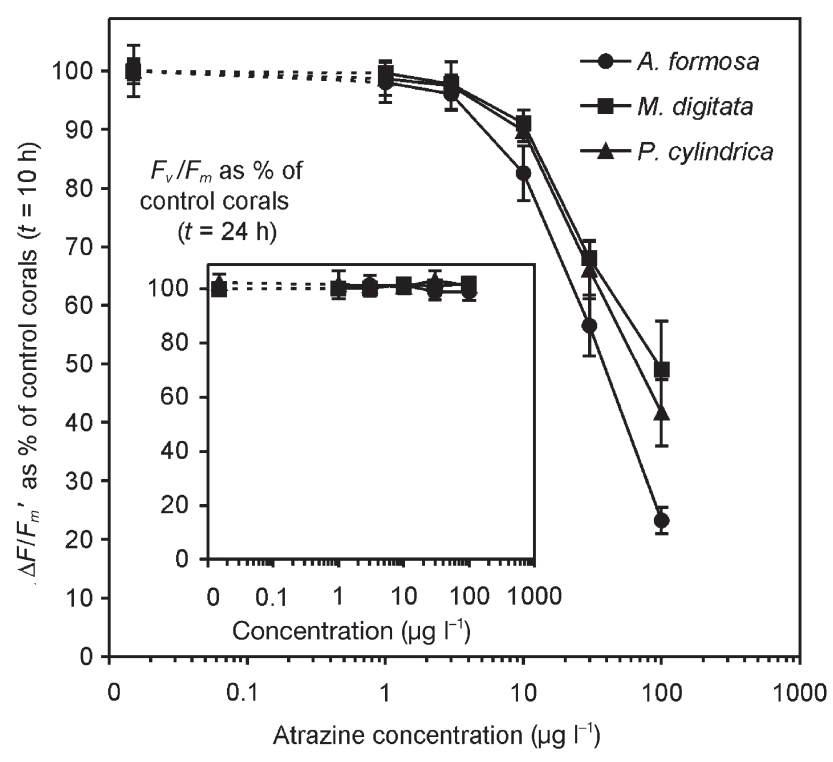

Fig. 3. Acropora formosa, Montipora digitata, and Porites cylindrica. $\Delta F / F_{m}$ ' of symbiotic dinoflagellates measured in hospite in 3 species of coral exposed to elevated atrazine concentrations in the range 1 to $100 \mathrm{\mu g} \mathrm{l}^{-1}$ for $10 \mathrm{~h}$. All measurements were made at the end of the $10 \mathrm{~h}$ light period. Inset: $F_{V} / F_{m}$ after $24 \mathrm{~h}$, measured at the end of the $14 \mathrm{~h}$ dark period. Data are mean $(\bar{x}) \pm S D, n=9$ 


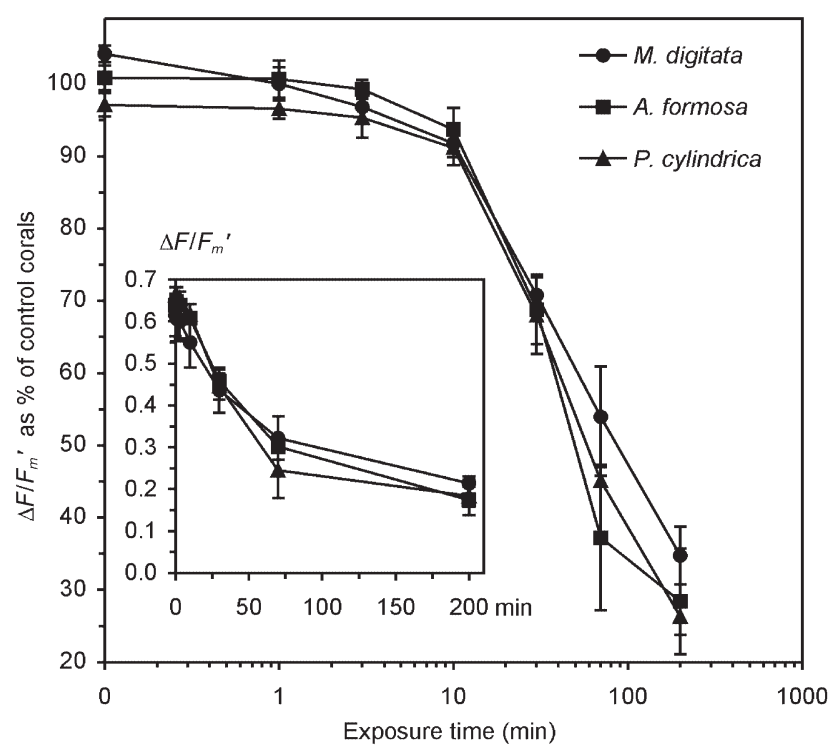

Fig. 4. Acropora formosa, Montipora digitata, and Porites cylindrica. $\Delta F / F_{m}{ }^{\prime}$ of symbiotic dinoflagellates measured in hospite in 3 species of coral exposed to $10 \mathrm{\mu g} \mathrm{l}^{-1}$ diuron for 240 min. Data are mean $(\bar{x}) \pm S D, n=3$ individual experiments. For each experiment 4 corals were exposed to diuron or ambient seawater, and $\Delta F / F_{m}{ }^{\prime}$ in the diuron-exposed corals expressed as a \% of control values. Inset: $\Delta F / F_{m}$ ' expressed as absolute values; data are mean $(\bar{x}) \pm \mathrm{SD}, \mathrm{n}=12$ corals

seawater for $24 \mathrm{~h}$ under a 10:14 h L:D cycle. At the end of the $10 \mathrm{~h}$ light period, $\Delta F / F_{m}{ }^{\prime}$ in diuron-treated corals was significantly lower than in the respective salinitycontrol corals for both species at both diuron concentrations tested (Fig. 6 ; ANOVA). Both $\Delta F / F_{m}{ }^{\prime}$ and $F_{V} / F_{m}$ under hypo-osmosis were similar to levels in normal salinity seawater for both species and there was no significant interaction between diuron concentration and salinity (2-way ANOVA, p < 0.05).

Fig. 7 shows the longer-term (96 h) experiments conducted under shaded natural sunlight (up to $1200 \mu \mathrm{mol}$ quanta $\mathrm{m}^{-2} \mathrm{~s}^{-1}$ ) and temperatures of 23.5 to $28.5^{\circ} \mathrm{C}$ (Fig. $7 \mathrm{C}$ ). $\Delta F / F_{m}^{\prime}$ (measured daily at solar noon) of symbiotic dinoflagellates from Montipora digitata exposed to diuron concentrations of 1, 10, 100 and $1000 \mu \mathrm{g} \mathrm{l}^{-1}$ was significantly different from that of control corals (Fig. 7A) during the $96 \mathrm{~h}$ exposure period. One day after being transferred back to running seawater, $\Delta F / F_{m}{ }^{\prime}$ was suppressed relative to the controls in corals exposed to 1000 and $100 \mu \mathrm{g} \mathrm{l}^{-1}$ only. Dark-adapted $F_{V} / F_{m}$, measured $2 \mathrm{~h}$ after sunset, was significantly different from control corals in corals exposed to 10,100 and $1000 \mu \mathrm{g} \mathrm{l}^{-1}$ during the $96 \mathrm{~h}$ exposure period. One day after being transferred back to a running seawater, $F_{v} / F_{m}$ was suppressed relative to the controls in corals exposed to 100 and $1000 \mu \mathrm{g} \mathrm{l}^{-1}$ only. During the toxicity tests, discolouration of the corals exposed to the 100 and $1000 \mu \mathrm{g} \mathrm{l}^{-1}$ diuron treatments was observed after $72 \mathrm{~h}$. There was a further discolouration of the corals during the observation period. The corals had turned from a normal dark brown pigmentation to a light cream colour by the end of the $8 \mathrm{~d}$ experiment. A slight discolouration of some of the corals in the $10 \mu \mathrm{g}$ $\mathrm{l}^{-1}$ diuron treatments was observed at the end of the observation period.

No significant differences were noted in the density of symbiotic dinoflagellates (range 2.4 to $2.5 \times 10^{6}$ symbiotic dinoflagellates $\mathrm{cm}^{-2}$ ) or the chlorophyll concentration per algal cell (range: 3.3 to 3.9 pg chlorophyll a per symbiotic dinoflagellate) between treatment controls (TC, held in static [24 h renewal] seawater over the $4 \mathrm{~d}$ exposure and subsequent $4 \mathrm{~d}$ observation period) and handling controls (HC, held in running seawater over the $8 \mathrm{~d}$ experiment). Analyses at the end of the observation period indicated $25 \%$ lower densities of symbiotic algae in the 100 and $1000 \mu \mathrm{g} \mathrm{l^{-1 }}$ treatments $(1.9 \pm 0.5$ and $1.9 \pm 0.6 \times$ $10^{6}$ symbiotic dinoflagellates $\mathrm{cm}^{-2}$ respectively $\bar{x} \pm \mathrm{SD}$, $\mathrm{n}=12$ ). These were significantly different from densities for the control corals. Chlorophyll a concentration per dinoflagellate cell was not significantly different between treatments (ANOVA, p > 0.05).

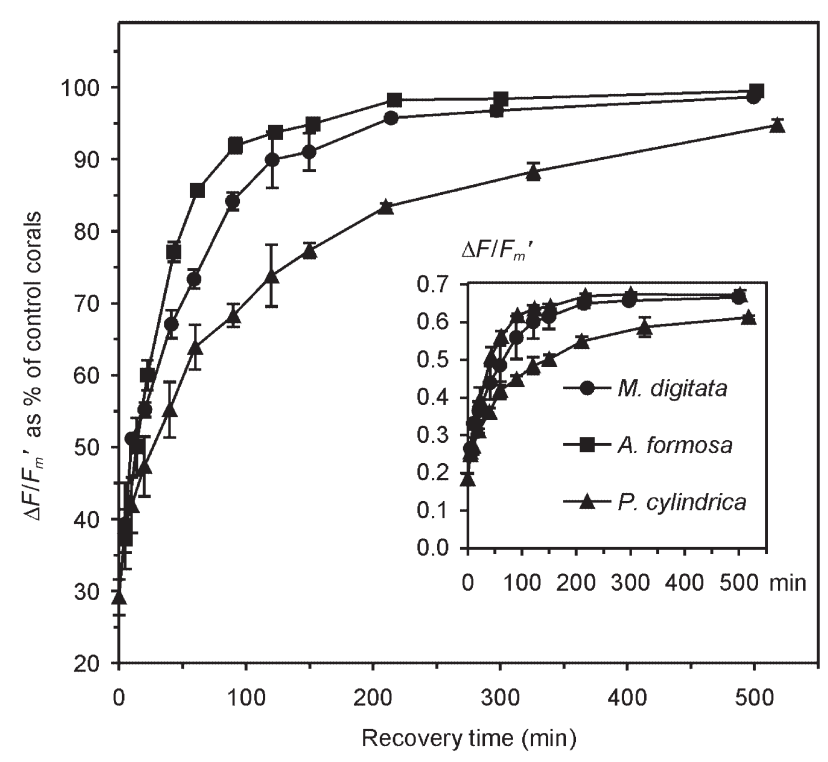

Fig. 5. Agropora formosa, Montipora digitata, and Porites cylindrica. $\Delta F / F_{m}{ }^{\prime}$ of symbiotic dinoflagellates measured in hospite in 3 species of coral exposed to $10 \mathrm{\mu g} \mathrm{l}^{-1}$ diuron for $240 \mathrm{~min}$ then returned to flowing seawater for a recovery period. Data are mean $(\bar{x}) \pm S D, n=3$ individual experiments. For each experiment 4 corals were exposed to diuron or ambient seawater and $\Delta F / F_{m}{ }^{\prime}$ in the diuron-exposed corals expressed as a $\%$ of control values. Inset: $\Delta F / F_{m}{ }^{\prime}$ expressed as absolute values. Data are mean $(\bar{x}) \pm \mathrm{SD}, \mathrm{n}=12$ corals 
As shown in Fig. 8, $\Delta F / F_{m}{ }^{\prime}$ in freshly isolated symbiotic algae from Stylophora pistillata was rapidly reduced during exposure to diuron, and significant differences were recorded between algae exposed to diuron concentrations $\geq 0.25 \mu \mathrm{g} \mathrm{l}^{-1}$ and algae exposed to the carrier only (Fig. 8, Inset B). $\Delta F / F_{m}{ }^{\prime}$ was reduced by 50 and $25 \%$ of the control values at $5.5\left(\mathrm{EC}_{50}\right)$ and $1.5\left(\mathrm{EC}_{25}\right) \mu \mathrm{g} \mathrm{l^{-1 }}$ diuron respectively. At $12 \mu \mathrm{g} \mathrm{l^{-1 }}$ diuron, $\Delta F / F_{m}{ }^{\prime}$ was $<50 \%$ of the control value before the first measurement at $\sim 30 \mathrm{~s}$ (Fig. 8, Inset C) and remained largely unchanged relative to the control value throughout the measuring period.

\section{DISCUSSION}

The recent detection of the herbicides diuron and atrazine in the nearshore marine environment along the Queensland coast, Australia, has raised concern about the World Heritage values of the Great Barrier Reef Marine Park (Haynes et al. 2000a). The present ecotoxicological evaluation of the effects of diuron on the symbiotic algae within the tissues of several coral species and on the isolated symbiotic algae indicates a rapid but reversible reduction in the photochemical

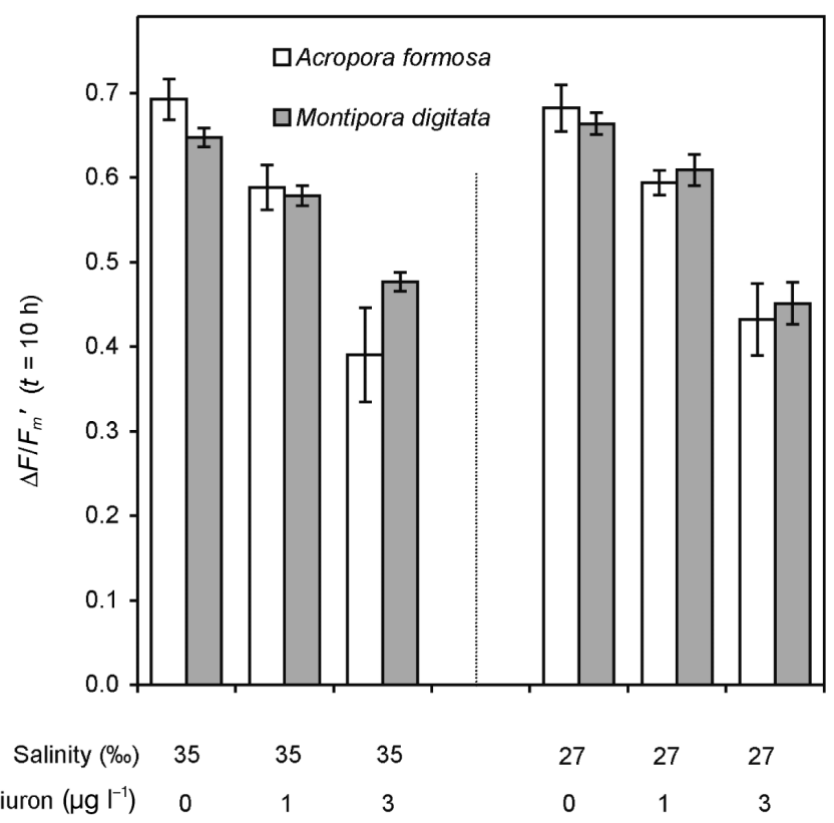

Fig. 6. Acropora formosa and Montipora digitata. $\Delta F / F_{m}$ ' of symbiotic dinoflagellates measured in hospite in corals exposed to 1 and $3 \mu \mathrm{g} \mathrm{l}^{-1}$ diuron concentrations for $24 \mathrm{~h}$ in normal $(35 \%)$ or reduced-salinity $\left(27 \%\right.$ ) seawater. $\Delta F / F_{m}^{\prime}$ measurements were made at the end of the light period $(t=10 \mathrm{~h})$. All data are mean $(\bar{x}) \pm \mathrm{SD}, \mathrm{n}=9$ corals, expressed as a $\%$ of control corals at either 35 or $27 \%$ o efficiency of the algae at exceptionally low concentrations. At higher concentrations, and over longer periods, the effect of diuron is not reversible and results in the sublethal 'dissociation' of the coral and its symbiotic algae (coral bleaching).

The mode of action of diuron is well known; it inhibits photosynthesis by reversibly binding to the $Q_{B}$
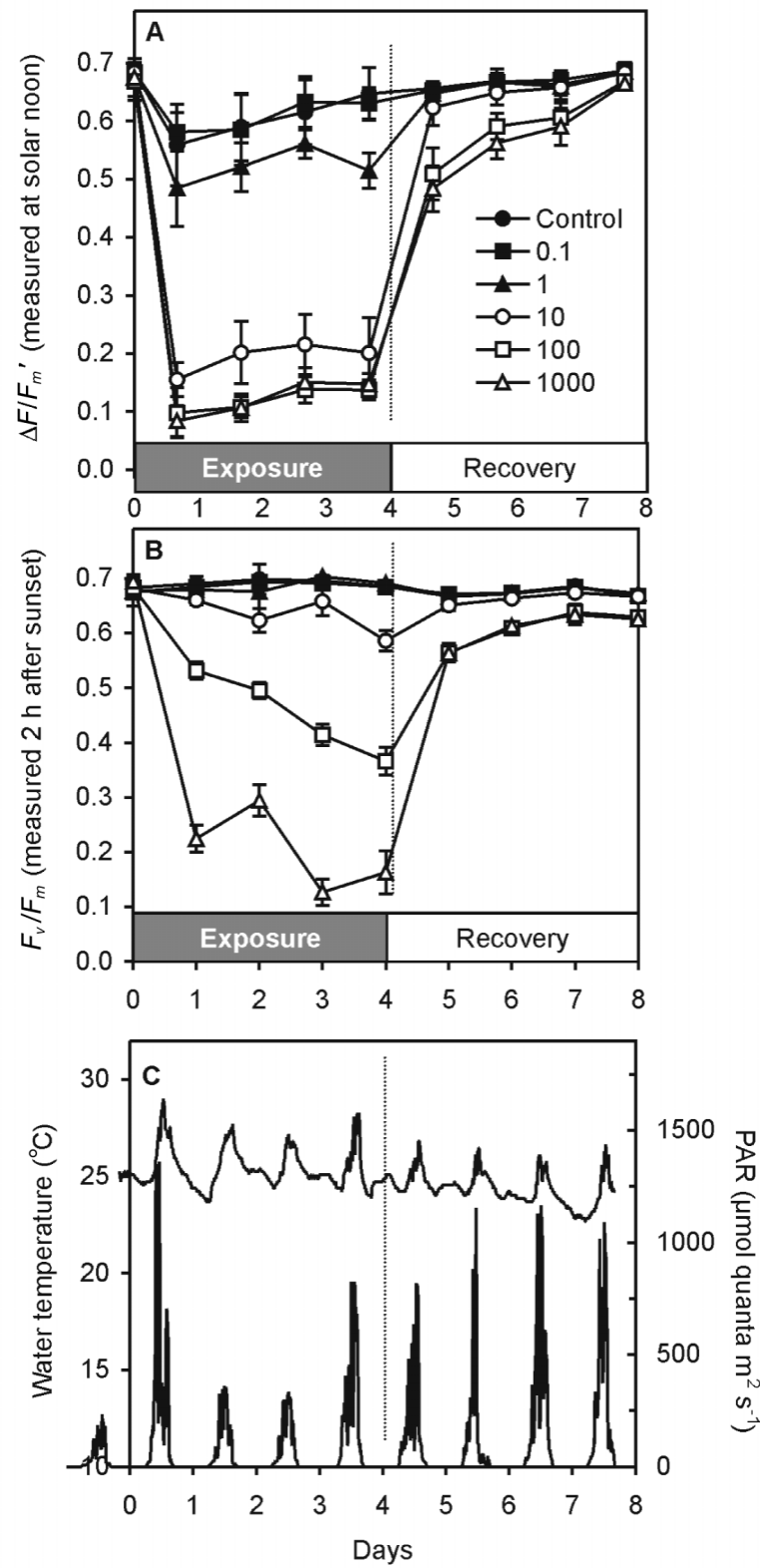

Fig. 7. Montipora digitata. (A) $\Delta F / F_{m}{ }^{\prime}$ and (B) $F_{v} / F_{m}$ of symbiotic dinoflagellates measured in hospite in coral exposed to 0.1 to $1000 \mu \mathrm{g} \mathrm{l}^{-1}$ diuron for $4 \mathrm{~d}$ (shaded area) and then returned to flowing seawater for $4 \mathrm{~d}$ observation period. Data are mean $(\bar{x}) \pm \mathrm{SD}, \mathrm{n}=9$ corals. (C) Temperature (top curve) and light measured during toxicity test and observation period 


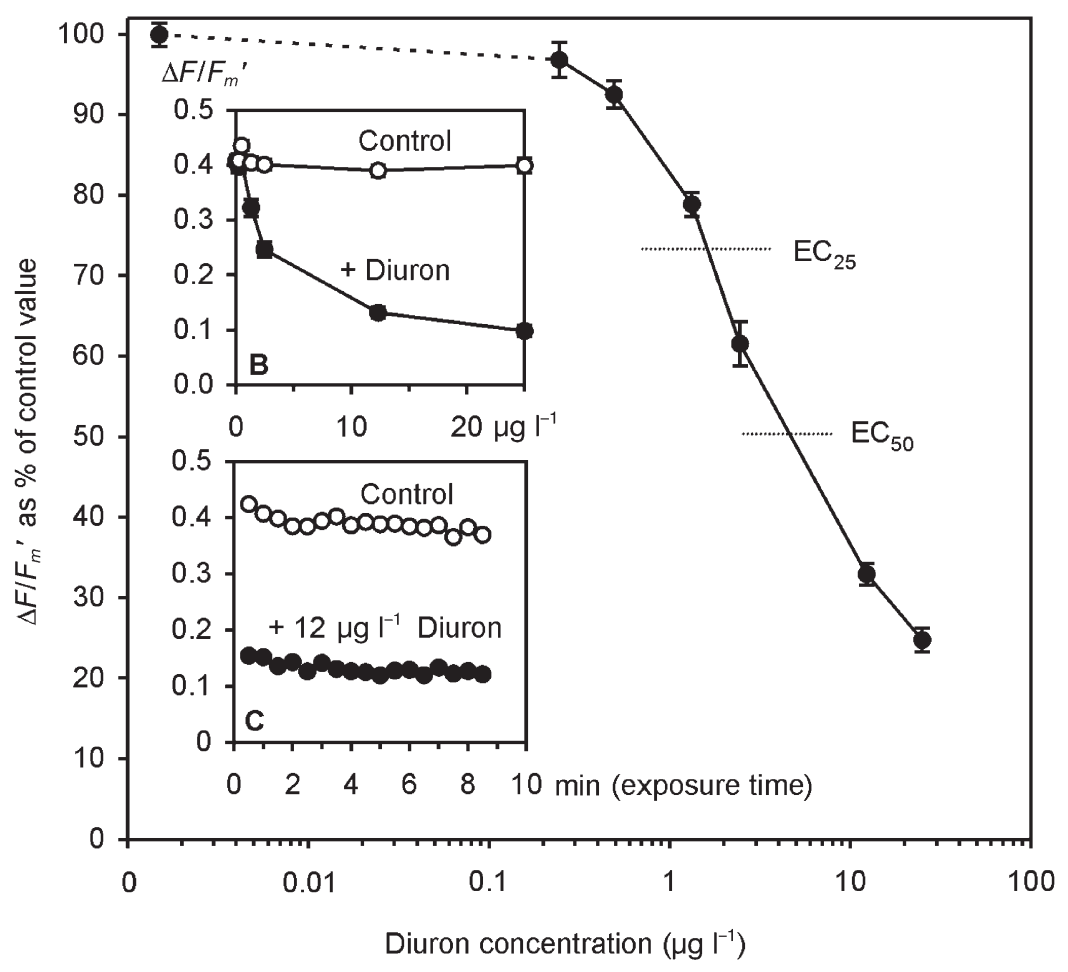

Fig. 8. Isolated symbiotic dinoflagellates. $\Delta F / F_{m}{ }^{\prime}$ in freshly isolated symbiotic dinoflagellates from the coral Stylophora pistillata exposed to elevated diuron concentrations in the range 0.25 to $25 \mathrm{\mu g} \mathrm{l}^{-1}$ expressed as \% of control values (exposed to carrier only); data are mean $(\bar{x}) \pm \mathrm{SD}, \mathrm{n}=12$ measurements (taken at $30 \mathrm{~s}$ intervals). Inset $\mathrm{B}$ : absolute $\Delta F / F_{m}{ }^{\prime}$ in control and diuron-exposed algae. Data are means, $\mathrm{n}=12$ measurements taken over a 6 min period. Inset $\mathrm{C}$ : $\Delta F / F_{m}^{\prime}$ in control algae and algae exposed to $12 \mu g \mathrm{l}^{-1}$ diuron diuron and atrazine, compete with plastoquinone for the binding site (Lavergne 1982). On the oxidising side of PS II the $\mathrm{P} 680^{+}$receives an electron via a tyrosine residue on the D1 protein, which in turn receives an electron from water via a manganese cluster and associated proteins. Over $50 \%$ of commercially available herbicides function by inhibition at the $\mathrm{Q}_{\mathrm{B}}$ site, and these 'classes' of herbicides include, amongst others, the ureas (e.g. diuron, fluometuron, linuron, siduron, tebuthiuron), $s$-triazines (e.g. atrazine, ametryn, cyanazine, simazine), triazinones (e.g. hexazinone, metribuzin), uracils (bromacil, terbacil), nitriles (bromoxynil), benzothiadiazoles (bentazon) and phenyl-pyridazines (pyridate).

In corals, the plant cells (symbiotic dinoflagellates) reside intracellularly within the host tissues (Muscatine et al. 1998). The algae are physically enclosed within a compartment (symbiosome) of an animal cell, defined by a single host-derived (animal) membrane and multiple underlying membrane layers thought to be of algal origin (Wakefield \& Kempf 2001). Herbicides, or other phytotoxic compounds, therefore need to cross multiple layers of animal tissues (including the ectoderm and mesoglea) and algal tissues binding site on the D1 protein (often called the 'herbicide-binding' protein), thus inhibiting electron flow (for a review on PS II herbicides see Oettmeier 1992). In photosynthesis, excitation energy from light absorption in the light-harvesting complex is transferred to the PS II reaction centre P680, where charge separation occurs. Electrons are transferred from the reaction centre chlorophyll P680 through phaeophytin (a specialised tetrapyrrol molecule corresponding to chlorophyll without the central magnesium) to $\mathrm{Q}_{\mathrm{A}}$, the first stable electron acceptor, which is tightly bound to the D2 protein. The electron is then passed to $Q_{B}$, a plastoquinone on the D1 protein, to produce the semiquinone form which remains tightly bound until it receives a second electron (from a second turnover of the reaction centre) and is protonated (extracting $2 \mathrm{H}^{+}$from the stroma). The $\mathrm{Q}_{\mathrm{B}} \mathrm{H}_{2}$ diffuses away from the PS II complex to become part of the plastoquinone pool (as a mobile electron carrier), eventually being oxidized by the cytochrome $b_{6} / f$ complex. The empty 'binding pocket' left on the D1 protein is filled by an oxidized plastoquinone molecule. PS II inhibitors, like (including also the 'pellicle' algal cell wall) before reaching the chloroplast target sites. This situation is unusual compared with that in phytoplankton, for example, which are in direct contact with the surrounding seawater. It needs to be considered when evaluating the effects of a toxicant. In addition, the symbiotic dinoflagellates in corals are located in several layers of tissue including the free-body wall, and density of algae is also particularly high, typically in the region of 1 to $4 \times 10^{6} \mathrm{~cm}^{-2}$. On a volume basis, these concentrations are many orders of magnitude higher than plankton densities in oligotrophic water and an order of magnitude higher than in nuisance plankton blooms (Cook \& D'Elia 1987). The high algal densities, especially in the upper endoderm, may also act as a barrier to herbicide penetration to the lower algaecontaining tissues. of $10 \mu \mathrm{g} \mathrm{l}^{-1}$ diuron were rapid, reducing $\Delta F / F_{m}^{\prime}$ to $<50 \%$ of control values before the first measurement (30 s). In vivo, the effects of diuron were slower; neverin deeper tissues in the calicoblastic endoderm. The

In the studies with isolated algae (in vitro), the effects 
theless, exposure to low $\left(10 \mu \mathrm{g} \mathrm{l}^{-1}\right)$ concentrations of diuron resulted in a reduction in $\Delta F / F_{m}{ }^{\prime}$ within minutes, and a $50 \%$ reduction in less than $2 \mathrm{~h}$ for all species. This response time was faster than that reported for the sea grass Halophila ovalis exposed to the same concentration under similar lighting conditions, in which a $50 \%$ reduction in $\Delta F / F_{m}{ }^{\prime}$ occurred in $\sim 24 \mathrm{~h}$ (Ralph 2000). In a further study with several sea grass species conducted outdoors (under shaded natural sunlight), Haynes et al. (2000b) also reported a $50 \%$ reduction in $\Delta F / F_{m}{ }^{\prime}$ in $H$. ovalis exposed to $10 \mu \mathrm{g}^{-1}$ diuron over $24 \mathrm{~h}$. The reduction in $\Delta F / F_{m}{ }^{\prime}$ in the other 2 species (Cymodocea serrulata and Zostera capricorni) tested by Haynes et al. (2000b) was noticeably faster, occurring within $2 \mathrm{~h}$. In the short-term toxicity tests, the effect of diuron was reversible and the transfer of diuron-exposed corals to running seawater resulted in a rapid recovery of $\Delta F / F_{m}{ }^{\prime}$ to the control levels within several hours, as the weakly bound diuron was washed from the corals.

Comparison of these values to those reported in studies with other algae is difficult due to differences in the nature and sensitivity of the parameters examined, the techniques used, and differences in the test species and test durations. From recent studies using chlorophyll fluorescence techniques, the $\mathrm{EC}_{50}$ of $5.5 \mathrm{\mu g}$ $\mathrm{l}^{-1}$ diuron for the isolated symbiotic dinoflagellates reported here is very similar to the $\mathrm{EC}_{50}$ for the marine microalgal diatom Phaeodactylum tricornutum (3.8 $\mathrm{\mu g}$ $\mathrm{l}^{-1}$ diuron), and for lyophilised lettuce thylakoids (also

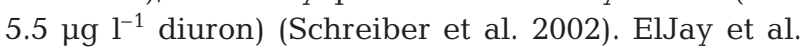
(1997), using chlorophyll fluorescence induction kinetics, also reported similar $\mathrm{EC}_{50}$ values for the freshwater chlorophyte Selenastrum capricornutum $\left(12 \mathrm{\mu g} \mathrm{l}^{-1}\right.$ for diuron and $64 \mathrm{\mu g} \mathrm{l}^{-1}$ for atrazine). Hayes et al. (2000b) reported an LOEC of $0.1 \mathrm{\mu g} \mathrm{l}^{-1}$ in the sea grasses Halophila ovalis and Zostera capricorni and between 1 and $10 \mathrm{\mu g} \mathrm{l}^{-1}$ diuron in Cymodocea serrulata. Ralph (2000) reported an LOEC of $10 \mathrm{\mu g} \mathrm{l}^{-1}$ for the effects of atrazine on $\Delta F / F_{m}{ }^{\prime}$ in $H$. ovalis. Using isolated PS II particles from the thermophilic cyanobacterium Synechococcus elongatus, Koblizek et al. (1998) showed a $50 \%$ decrease in oxygen evolution at $20 \mathrm{\mu g} \mathrm{l}^{-1}$ diuron and $65 \mathrm{\mu g} \mathrm{l}^{-1}$ for atrazine. The symbiotic dinoflagellates of corals appear to be as equally sensitive to the herbicidal effects of diuron and atrazine as the organisms described in those studies.

In contrast to $\Delta F / F_{m}{ }^{\prime}$, the chlorophyll fluorescence parameter $F_{V} / F_{m}$ was less sensitive in assessing the effects of diuron and atrazine. Differences in relative extents of lowering of $\Delta F / F_{m}{ }^{\prime}$ and $F_{V} / F_{m}$ by diuron and other inhibitors of photosynthetic electron transport are due to the empirical fact that after dark-adaptation PS II reaction centres are open, independent of inhibition of electron transport. Any electron accumulated at the PS II acceptor side during illumination will be taken up in the dark by molecular oxygen or will recombine with positive charges at the PS II donor side. Hence, for optimal detection of inhibition, the rate of charge separation at PS II must exceed the rate of PS II recombination as well as the rate of $\mathrm{O}_{2}$ reduction. It follows that there is an optimal light intensity for maximal inhibition of PS II energy conversion rate (measured via $\Delta F / F_{m}{ }^{\prime}$ ), as recently reported by Schreiber et al. (2002). In the studies conducted here, the effects of diuron was clearly more pronounced in Seriatopora hystrix at $25 \mu \mathrm{mol}$ quanta $\mathrm{m}^{-2} \mathrm{~s}^{-1}\left(\mathrm{EC}_{50}=\right.$ $2.9 \mathrm{\mu g} \mathrm{l}^{-1}$, LOEC $=0.3 \mu \mathrm{g} \mathrm{l}^{-1}$ diuron) than at $100 \mu \mathrm{mol}$ quanta $\mathrm{m}^{-2} \mathrm{~s}^{-1}\left(\mathrm{EC}_{50}=3.9 \mu \mathrm{g} \mathrm{l}^{-1}, \mathrm{LOEC}=1 \mu \mathrm{g} \mathrm{l}^{-1}\right.$ diuron). If an inhibitor induces a lowering of $F_{V} / F_{m}$ even at very low measuring light intensity, this points to a direct block of PS II reaction centres, e.g. by photoinhibition. This was occasionally observed in the short-term toxicity studies with diuron (but not with atrazine), and was observed during the diuron exposure tests conducted outdoors under high light levels (see below).

There was some evidence (also in unreported preliminary range-finding tests) to suggest that Montipora digitata is less sensitive to diuron and atrazine than the other species tested, although the recorded effect was slight. Differential sensitivity of algae to individual herbicides has been reported previously, and Hollister \& Walsh (1973) described differences between 6 phyla of phytoplankton and 1 benthic cyanobacterium. The cause of the difference has generally not been attributed to differences in the architecture of the herbicidebinding site, as the amino acid sequence of the D1 protein in photoautotrophs is amongst the most highly conserved of photosynthetic proteins (Barber 1992). In the tests conducted here, all 4 coral species belonged to a single phylogenetic clade or subgenus (' $\mathrm{C}$ ') comprised of closely related types (as assessed by denaturing gradient gel electrophoresis [DGGE] analysis of the internal transcribed spacer region 2, Todd LaJeunesse pers. comm.). Any differences are therefore unlikely to be due to genetic variation of the algae. Differences in herbicide sensitivity between individual algal species have usually been attributed to differential cell permeability and herbicide uptake (for example Fahl et al. 1995). Thus, slight differences in the sensitivity of the coral species may reflect variations in target-site delivery, which would also encompass the characteristics of the animal (coral) host cell. Also, differences in sensitivity between coral species may be caused by differences in the light intensity under which the measurements were made, which has to be optimised for a given species and a given photoacclimatory state of the algal symbionts (see preceding paragraph). Even when collecting corals from the same 
depth and habitat, subtle differences in the colony shape and morphology (incorporating self-shading and branch orientation and proximity to the nearest neighbouring branch), will significantly influence the photoacclimatory state of the algae and consequently the subsequent outcome of a test. Overall, after considering these points, we prefer to emphasise (1) the similarity of the response of the coral species tested to the individual herbicides rather than the differences, (2) the higher levels of toxicity of diuron than atrazine to the symbiotic algae of the corals (assessed as a reduction in the fluorescence parameter $\Delta F / F_{m}{ }^{\prime}$ ).

Collectively, the results of the short-term toxicity studies, and uptake and recovery studies, indicate that despite the intracellular location of the photosymbionts and the high algal densities, diuron is a fast-acting and potentially reversible inhibitor of photosynthesis at exceptionally low concentrations. In the longer-term exposures conducted under natural light (maximum $1200 \mu \mathrm{mol}$ quanta $\mathrm{m}^{-2} \mathrm{~s}^{-1}$ PAR) as well as at higher diuron concentrations, the effects were longer-lasting. In these experiments, chlorophyll fluorescence parameters were measured during the daytime (at solar noon, $\left.\Delta F / F_{m}{ }^{\prime}\right)$ and $2 \mathrm{~h}$ after sunset $\left(F_{v} / F_{m}\right)$. Initially, $\Delta F / F_{m}{ }^{\prime}$ decreased significantly also at the lower (i.e. 1 and $10 \mu \mathrm{g} \mathrm{l}^{-1}$ ) diuron concentrations, whilst marked decreases in $F_{v} / F_{m}$ were only recorded at the higher (100 and $1000 \mathrm{~g} \mathrm{l}^{-1}$ ) concentrations. There was a tendency towards a lowering of $F_{V} / F_{m}$ in the 10, 100 and $1000 \mathrm{~g} \mathrm{l}^{-1}$ diuron treatments with time, which was distinctly slower than inhibitor-binding. Lowering of $F_{V} / F_{m}$ was paralleled by a slow recovery of $\Delta F / F_{m}{ }^{\prime}$. This suggests that the long-term lowering of $F_{\mathrm{v}} / F_{m}$ during the exposure period and initial part of the recovery period is indicative of photoinhibition, as secondary damage to PS II reaction centres. Many studies have shown that the action of PS II-based herbicides is enhanced by light (Kunert \& Dodge 1989). Ultimately, the long-term phytotoxic effects of triazine and phenylureas herbicides are likely to involve the photo-peroxidation of the thylakoid and other cell membranes. This usually occurs via active oxygen species, caused by triplet chlorophyll photosensitised reactions and in turn is related to the inability of chlorophylls to dissipate excess energy when the natural defense mechanisms become exhausted (Asada \& Takahashi 1987, Halliwell 1991). Production of active oxygen species is a particular problem in corals (for examples see Lesser $1996,1997)$, in which tissue hyperoxia ( $>250 \%$ of air saturation) is rapidly reached upon illumination (Kühl et al. 1995).

At the higher diuron concentrations tested, 'bleaching' occurred. Bleaching of corals is different from the herbicide-mediated 'bleaching' of plants caused by the destruction of chlorophylls and carotenoids (or inhibi- tion of their formation). Although both processes lead to a general lightening of colouration, bleaching in corals is largely caused by the physical separation or 'dissociation' of the coral and its symbiotic algae (for a review see Fitt et al. 2001). Coral bleaching is a sublethal stress response that causes the tissues to lighten in colour as the brown algae are lost from the coral. Corals without pronounced pigments in the animal tissues appear to turn white. Bleaching in response to environmental contaminants or changes in environmental conditions is a common response (for examples see Jones et al. 1999), and has been proposed as a useful effect criterion for ecotoxicological studies (Jones 1997b, Meehan \& Ostrander 1997). Sometimes in bleached corals (with lower densities of algae), the remaining algae also have lower concentrations of chlorophyll (Kleppel et al. 1989), and this may contribute to some of the observed discolouration. However, this is often not the case and the chlorophyll concentration of the remaining algae may even be higher in corals that have lost symbiotic dinoflagellates and become discoloured (Jones 1997b, Brown et al. 2000). Sometimes corals can turn pale by extreme retraction of the tissues, which exposes the skeletal septae. This behavioural response may not involve a loss of symbiotic dinoflagellates or changes in chlorophyll concentration of the algae, but can give rise to a substantial change in coral colouration (Brown et al. 1994). The response is usually reversible within hours and has mostly been described in response to sub-aerial exposure.

Bleached Montipora digitata exposed to higher concentrations of diuron had a lower density of symbiotic dinoflagellates in their tissues than control corals. The chlorophyll concentration per algal cell of the remaining algae, however, was similar to that in the normally pigmented corals used as controls for the handling and manipulation procedures. Visually the corals appeared very pale (bleached), which is surprising given that they had lost only $\sim 40 \%$ of their symbiotic algae. In Acropora formosa, for example, corals only start discolouring when they have lost $\sim 40$ to $50 \%$ of their algae (Jones 1997b). Considering also that the M. digitata colonies have naturally high densities of symbiotic algae ( 3 to $4 \times 10^{6}$ cells $\mathrm{cm}^{-2}$ ), that the diuronexposed bleached corals still retained comparatively high algal densities $\left(\sim 2 \times 10^{6} \mathrm{~cm}^{-2}\right)$, and that no loss of chlorophyll per algal cell was recorded, the observed high level of pigment discoluration is even more remarkable. During the recovery period the surface of the bleached corals had a distinctly granular texture when lightly touched, suggesting exposure of the coral skeleton via pronounced tissue retraction. As discussed in Brown et al. (1994), tissue retraction may be a protective response of the coral against high levels of 
radiation, and in a retracted state the symbiotic dinoflagellates may be afforded protection (shielded) by the skeletal elements, animal tissue layers and also mucus. Bleaching in diuron-exposed $M$. digitata is thus likely to be caused by both a loss of symbiotic dinoflagellates (a physiological response) and by tissue retraction (a behavioural response).

Bleaching, as a reduction in algal symbionts, was correlated with a long-term reduction in $F_{v} / F_{m}$ of the symbiotic algae. This has also been observed following cyanide exposure (Jones \& Hoegh-Guldberg 1999), heat stress (Jones et al. 2000), and exposure to reduced-salinity seawater (Kerswell \& Jones in press). Our study further indicates the effectiveness of the chlorophyll fluorescence techniques and the fluorescence parameter $F_{V} / F_{m}$ in identifying when dissociation of the coral-algal symbiosis will occur following exposure to pollutants or altered environmental conditions. The gradual improvement of $F_{V} / F_{m}$ in the diuron-exposed corals during the recovery period can be interpreted in different ways. The recovery may be attributable to PS II repair processes within the algae, but equally to the export of damaged algae (those with lower yields) from the corals, or presumably to both processes (see Jones \& Hoegh-Guldberg 1999). In this context, it is also important that a fully competent PS II donor-side (water-splitting) is a prerequisite for measuring maximal $F_{v} / F_{m}$ values. In order to reach $F_{m}$ during a saturation pulse, both $\mathrm{Q}_{\mathrm{A}}$ and the plastoquinone pool has to be fully reduced. This is possible only if water-splitting is active. Photoinhibition is known to cause damage at both PS II donor and acceptor sites.

Inshore corals of the Great Barrier Reef Marine Park potentially experience the highest concentrations of terrestrial-derived pollutants during flood events, especially those associated with short-term extreme flow events. It is unknown whether a reduction in salinity can alter the effects of herbicides on corals. Recently, Kerswell \& Jones (in press) reported that exposure of the coral Stylophora pistillata to reducedsalinity seawater alone can cause a reduction in the photochemical efficiency of its algal symbionts and can also induce coral bleaching. Whilst exposing Acropora formosa and Montipora digitata to $27 \%$ for only $10 \mathrm{~h}$ did not cause a reduction in photochemical efficiency of algal symbionts, elevated diuron concentrations reduced $\Delta F / F_{m}$ ' in either the normal or reduced-salinity seawater. There was, however, no significant interactive effects of diuron and reduced salinity. This suggest that at the salinity level tested, and over the $10 \mathrm{~h}$ exposure period, hypo-osmosis did not exacerbate the herbicidal effects of diuron.

Photosynthesis of the symbiotic dinoflagellates of corals (Symbiodinium spp.) and translocation of pho- tosynthate (hence energy) to the coral host, together with the recycling of the nutrients within the symbiosis, are keys to the success of corals in the oligotrophic waters of tropical oceanic systems (Falkowski et al. 1993). The calcification rate of corals also appears to be enhanced by symbiosis with dinoflagellate algae (Gattuso et al. 1999), and the calcification process contributes significantly to reef accretion and the development of reef ecosystems. The study has shown that diuron can affect the photochemical efficiency of the algal symbionts of corals at exceptionally low concentrations (less than $1 \mathrm{gg} \mathrm{l}^{-1}$ ). Diuron and atrazine concentrations in inshore coastal areas of the GBR, where corals are found, have not been measured. Currently programs are underway to monitor seasonal herbicide concentrations in marinas and harbours in the tropics as well as in coastal waters during flood plumes. Furthermore, new programs involving novel in situ passive and active sampling techniques that allow time-integrated analyses of pollutants such as diuron and atrazine are about to commence. Given the toxicity of diuron to photosynthesis, it follows that its 'intentional' release into the Great Barrier Reef World Heritage Area (through its use in antifouling paint formulations) should only be permitted with adequate knowledge of the associated risks. In this respect, diuron has recently (2001 and 2002) been phased out of use as a 'booster' biocide in antifouling paints in the United Kingdom, amidst concerns over its environmental effects on aquatic ecosystems. The 'accidental' release of diuron, in agricultural runoff, should clearly also be a cause for concern. In a recent study of water quality in a moderate (1 in 2 yr) 'highflow' event in the Pioneer catchment, riverine diuron concentrations of $8.5 \mathrm{\mu g} \mathrm{l}^{-1}$ were detected in water that flows into the central section of the GBRMP (with estimated export loads of $470 \mathrm{~kg}$ of diuron: White et al. 2002). Johnson \& Ebert (2000) described marked changes in rural land use and cover and increases in the use of pesticides in a representative catchment area draining into the GBRMP. Whilst acknowledging that the fate of the pesticides in the aquatic and marine environment is unknown, they comment that the trends associated with pesticide use in the GBR catchment poses a significant challenge for agricultural industries to comply with the principles of ecological sustainable development (ESD). The movement of agricultural chemicals, such as diuron and atrazine, to the aquatic and marine environment and their effects on keystone species have now been investigated and are becoming better understood (Hargreaves et al. 1999, Haynes et al. 2000a,b, Müller et al. 2000, Ralph 2000, Simpson et al. 2001, Baskaran et al. 2002, White et al. 2002, present study). 
Acknowledgements. This work received funding assistance from a Strategic Partnership with Industry Research and Training (SPIRT) award from the Australian Research Council (ARC), from the Great Barrier Reef Marine Parks Authority (GBRMPA), The Townsville City Council, and the Natural Heritage Trust (Australia) under the Anti-fouling Program Project \#29298.

\section{LITERATURE CITED}

Alzieu C (1996) Biological effects of tributyltin on marine organisms. In: DeMore SJ (ed) Tributyltin: case study of an environmental contaminant. Cambridge University Press, Cambridge, p 167-211

Asada K, Takahashi M (1987) Production and scavenging of active oxygen in photosynthesis. In: Kyle DJ, Osmond CB, Arntzen CJ (eds) Photoinhibition. Elsevier, Amsterdam, p 227-287

Barber J (1992) Photosynthetic reaction centres: a common link. Trends Biol Sci 12:321-326

Baskaran S, Budd KL, Larsen RM, Bauld J (2002) A groundwater quality assessment of the lower Pioneer Catchment, Queensland Bureau of Rural Services, Department of Agriculture Fisheries and Forestry, Canberra

Boxall ABA, Comber SD, Conrad AU, Howcroft J, Zaman N (2000) Inputs, monitoring and fate modelling of antifouling biocides in UK estuaries. Mar Pollut Bull 40:898-905

Brodie J, Christie C, Devlin M, Haynes D, Morris S, Ramsay S, Waterhouse J, Yorkston H (2001) Catchment management and the Great Barrier Reef. Water Sci Technol 43:203-211

Brown BE, Le Tissier MDA, Dunne RP (1994) Tissue retraction in the scleractinian coral Coeloseris mayeri, its effect upon coral pigmentation, and preliminary implications for heat balance. Mar Ecol Prog Ser 105:209-218

Brown BE, Dunne RP, Goodson MS, Douglas AE (2000) Bleaching patterns in reef corals. Nature 404:142-143

Butler WL (1978) Energy distribution in the photochemical apparatus of photosynthesis. Annu Rev Plant Physiol 29: 345-378

Cook CB, D'Elia CF (1987) Are natural populations of zooxanthellae ever nutrient-limited? Symbiosis 4:199-212

Duke NC, Roelfsema C, Tracey D, Godson L (2001) Preliminary investigation into dieback of mangroves in the Mackay region: initial assessment and possible causes. Research report submitted to the Queensland Fisheries Service, Northern Region (DPI) and the Community of Mackay Region. Report prepared by Marine Botany, The University of Queensland, Brisbane

ElJay A, Ducruet JM, Duval JC, Pelletier JP (1997) A highsensitivity chlorophyll fluorescence assay for monitoring herbicide inhibition of Photosystem II in the chlorophyte Selenastrum capricornutum: comparison with effect in cell growth. Arh Hydrobiol 140:273-286

Evans SM, Birchenough AC, Brancanto MS (2000) The TBT ban: out of the frying pan into the fire? Mar Pollut Bull 40: 204-211

Fahl GM, Kreft L, Altenburger R, Faust M, Boedeker W, Grimme LH (1995) pH dependent sorption, bioconcentration and algal toxicity of sulfonylurea herbicides. Aquat Toxicol 31:175-187

Falkowski PG, Dubinsky Z, Muscatine L, McCloskey L (1993) Population control in symbiotic corals. BioScience 43: 606-611

Fitt WK, Brown BE, Warner ME, Dunne RP (2001) Coral bleaching: interpretation of thermal tolerance limits and thermal thresholds in tropical corals. Coral Reefs 20:51-65
Furnas MJ, Brodie J (1996) Current status of nutrient levels and other water quality parameters in the Great Barrier Reef. In: Hunter HM, Eyles AG, Rayment GE (eds) Downstream effects of land use. Queensland Department of Natural Resources, Rockhampton, p 9-21

Gattuso JP, Allemand D, Frankignoulle M (1999) Photosynthesis and calcification at cellular, organismal and community levels in coral reefs: a review on interactions and control by carbonate chemistry. Am Zool 39:160-183

Halliwell B (1991) Oxygen radicals: their formation in plant tissues and their role in herbicide damage. In: Baker NR, Percival MP (eds) Herbicides. Elsevier Science Publishers, Amsterdam, p 87-129

Hamilton D, Haydon G (1996) Pesticides and fertilisers in the New South Wales sugar industry-estimates of usage and likely environmental fate. Department of Primary Industries, Resource Management Institute, Indooroopilly, Brisbane, Qld

Hargreaves PA, Simpson BW, Ruddle LJ, Packett R (1999) Persistence and fate of pesticides in sugarcane soils. Proc Aust Soc Sugar Cane Technol 21:287-293

Haynes D, Müller J, Carter S (2000a) Pesticide and herbicide residues in sediments and seagrasses from the Great Barrier Reef World Heritage Area and Queensland coast. Mar Pollut Bull 41:279-287

Haynes D, Ralph P, Prange J, Dennison B (2000b) The impact of the herbicide diuron on photosynthesis in 3 species of tropical seagrass. Mar Pollut Bull 41:288-293

Haynes D, Christie C, Marshall P, Dobbs K (2003) Antifoulant concentrations at the site of the Bunga Teratai Satu grounding, Great Barrier Reef, Australia. Mar Pollut Bull 44:968-972

Hollister TA, Walsh GE (1973) Differential responses of marine phytoplankton to herbicides: oxygen evolution. Bull Environ Contam Toxicol 9:291-295

Hunter H, Sologinkin S, Choy S, Hooper A, Allen W, Raymond M, Peeters J (2001) Water management in the Johnstone Basin. Queensland Department of Natural Resources and Mines, Brisbane

Johnson AKL, Ebert SP (2000) Quantifying inputs of pesticides to the Great Barrier Reef Marine Park - a case study in the Herbert river catchment of north-east Queensland. Mar Pollut Bull 41:302-309

Jones RJ (1997a) Zooxanthellae loss as a bioassay for assessing stress in corals. Mar Ecol Prog Ser 149:163-171

Jones RJ (1997b) Changes in zooxanthellar densities and chlorophyll concentrations in corals during and after a bleaching event. Mar Ecol Prog Ser 158:51-59

Jones RJ, Hoegh-Guldberg O (1999) Effects of cyanide on coral photosynthesis: implications for identifying the cause of coral bleaching and for assessing the environmental effects of cyanide fishing. Mar Ecol Prog Ser 177:83-91

Jones RJ, Hoegh-Guldberg O (2001) Diurnal changes in the photochemical efficiency of the symbiotic dinoflagellates (Dinophyceae) of corals: photoprotection, photoinactivation and the relationship to coral bleaching. Plant Cell Environ 24:89-100

Jones RJ, Ward S, Yang-Amri, Hoegh-Guldberg O (2000) Changes in quantum efficiency of Photosystem II of symbiotic dinoflagellates of corals after heat stress and during the 1998 Great Barrier Reef mass bleaching event. Mar Freshw Res 51:63-71

Kleppel GS, Dodge RE, Reese CJ (1989) Changes in pigmentation associated with the bleaching of stony corals. Limnol Oceanogr 34:1331-1335

Kerswell AP, Jones RJ (in press) Effects of hypo-osmosis on the coral Stylophora pistillata: the nature and cause of 'low 
salinity bleaching' and implications for management. Mar Ecol Prog Ser

Koblizek M, Masojidek J, Komenda J, Kucera T, Pilloton R, Mattoo AK, Giardi MT (1998) A sensitive Photosystem IIbased biosensor for detection of a class of herbicides. Biotechnol Bioeng 60:664-669

Kookana RS, Baskaran S, Naidu R (1998) Pesticide fate and behaviour in Australian soils in relation to contamination and management of soil and water: a review. Aust J Soil Res 36:715-764

Krause G, Weis E (1991) Chlorophyll fluorescence and photosynthesis: the basics. Annu Rev Plant Physiol Plant Mol Biol 42:313-349

Kühl M, Cohen Y, Dalsgaard T, Jørgensen BB, Revsbech NP (1995) Microenvironment and photosynthesis of zooxanthellae in scleractinian corals studied with microsensors for $\mathrm{O}_{2}, \mathrm{pH}$ and light. Mar Ecol Prog Ser 117:159-172

Kunert KJ, Dodge AD (1989) Herbicide-induced radical damage and antioxidative systems. In: Böger PB, Sandmann G (eds) Target sites of herbicide action. CRC Press, Boca Raton, FL, p 45-63

Lesser MP (1996) Elevated temperatures and ultraviolet radiation cause oxidative stress and inhibit photosynthesis in symbiotic dinoflagellates. Limnol Oceanogr 41:271-283

Lesser MP (1997) Oxidative stress causes coral bleaching during exposure to elevated temperatures. Coral Reefs 16: 187-192

Martinez K, Ferrer I, Hernando MD, Fernandez-Alba AR, Marce RM, Borrull F, Barcelo D (2001) Occurrence of antifouling biocides in the Spanish Mediterranean marine environment. Environ Technol 22:543-552

Meehan WJ, Ostrander GK (1997) Coral bleaching: a potential biomarker of environmental stress. J Toxicol Environ Health 50:529-552

Müller JF, Duquesne S, Ng J, Shaw GR, Krrishnamohan K Manonmanii K, Hodge M, Eaglesham GK (2000) Pesticides in sediments from Queensland irrigation channels and drains. Mar Pollut Bull 41:294-301

Muscatine L, Ferrier-Pages C, Blackburn A, Gates RD, Baghdasarian G, Allemand D (1998) Cell-specific density of symbiotic dinoflagellates in tropical anthozoans. Coral Reefs 17:329-337

Noble RM, Duivenvoorden LJ, Rummenie SK, Long PE, Fabbro LD (1997) Downstream effects of land use in the Fitzroy Catchment. Summary Report Queensland Department of Natural Resources, Brisbane

Oettmeier W (1992) Herbicides of Photosystem II. In: Barber J (ed) The photosystems: structure, function and molecular biology, Vol II. Elsevier, Amsterdam, p 349-408

Ralph PJ (2000) Herbicide toxicity of Halophila ovalis assessed by chlorophyll a fluorescence. Aquat Bot 66:141-152

Editorial responsibility: Otto Kinne (Editor),

Oldendorf/Luhe, Germany
Rand GM, Petrocelli SR (1985) Fundamentals of aquatic toxicology. Hemisphere Publishing, Washington, DC

Scarlett A, Donkin P, Fileman TW, Morris RJ (1999) Occurrence of the antifouling herbicide, Irgarol 1051, within coastal-water seagrasses from Queensland, Australia. Mar Pollut Bull 38:687-691

Schreiber U, Bilger W, Neubauer C (1994) Chlorophyll fluorescence as a non-intrusive indicator for rapid assessment of in vivo photosynthesis. In: Schulze ED, Caldwell MM (eds) Ecophysiology of photosynthesis. Series Ecological Studies, Vol 100. Springer-Verlag, Berlin, p 49-70

Schreiber U, Müller JF, Haugg A, Gademann R (2002) New type of dual channel PAM chlorophyll fluorometer for highly water toxicity biotests. Photosynth Res 74:317-330

Simpson BW, Hargreaves PA, Umrit G (1999) Movement and persistence of pesticides in tropical sugarcane production. In: Aggarwal BS, Dureja P, Dikshit AK (eds) AbstractsSecond International Conference on Contaminants in the Soil Environment in the Australasia-Pacific region, December 1999. New Delhi, p 347-348

Stewart C (1996) The efficacy of legislation in controlling tributyltin in the marine environment. In: De Mora SJ (ed) Tributyltin: case study of an environmental contaminant. Cambridge University Press, Cambridge, p 264-297

Stimson J, Kinzie RA (1991) The temporal pattern and rate of release of zooxanthellae from the reef coral Pocillopora damicornis (Linnaeus) under nitrogen-enrichment and control conditions. J Exp Mar Biol Ecol 153:63-74

Thomas KV, Blake SJ, Waldock MJ (2000) Antifouling paint booster biocide contamination in UK marine sediments. Mar Pollut Bull 40:739-745

Voulvoulis N, Schrimshaw MD, Lester JN (1999) Alternative antifouling biocides. Appl Organomet Chem 13: 135-143

Voulvoulis N, Scrimshaw MD, Lester JN (2000) Occurrence of four biocides utilized in antifouling paints, as alternatives to organotin compounds, in waters and sediments of a commercial estuary in the UK. Mar Pollut Bull 40: 938-946

Wakefield T, Kempf S (2001) Development of host- and symbiont-specific monoclonal antibodies and confirmation of the origin of the symbiosome membrane in a Cnidariandinoflagellate symbiosis. Biol Bull (Woods Hole) 200: 127-143

White I, Brodie J, Mitchell C (2002) Pioneer River catchment event based water quality sampling. Mackay Whitsundays Healthy Waterways Program, Mackay Whitsunday Regional Strategy Group, Mackay

Williams DMcB (2001) Impacts of terrestrial run-off on the GBRWHA. Report to CRC Reef. CRC Reef Research Centre, Townsville

Submitted: August 23, 2002; Accepted: November 6, 2002 Proofs received from author(s): March 11, 2003 